\title{
Firewood and Carpentry Wood Contribution to The Communities of Mutis Timau Protected Forest, Timor Island
}

\author{
Fransiskus Xaverius Dako ${ }^{* *}$, Ris Hadi Purwanto², Lies Rahayu Wijayanti Faida ${ }^{3}$, Sumardi $^{4}$ \\ ${ }^{1}$ Graduate Program of Forestry Science, Faculty of Forestry Gadjah Mada University, Yogyakarta, Indonesia 55281 \\ ${ }^{2}$ Department of Forest Management, Faculty of Forestry, Gadjah Mada University, Yogyakarta, Indonesia 55281 \\ ${ }^{3}$ Department of Forest Resource Conservation, Faculty of Forestry, Gadjah Mada University, Yogyakarta, Indonesia 55281 \\ ${ }^{4}$ Department of Silviculture, Faculty of Forestry, Gadjah Mada University, Yogyakarta, Indonesia 55281
}

Received October 4, 2018 /Accepted December 23, 2018

\begin{abstract}
The existence of Mutis Timau Protected Forest (MTPF) has given a real contribution to the community by providing household energy needs and raw materials for building the houses. This preliminary study is aimed at knowing the contribution of MT PF in terms of firewood and carpentry wood consumption in the community. The study was conducted in 9 villages located in and around MTPF. This study used surveys and employed descriptive analysis with 353 families spread proportionally on every village as the sample. The results show that MTPF contributed to as much as $87.45 \%$ of the total firewood consumption of the community living in and around the protected forest, while the remaining $12.55 \%$ was supplied from the gardens. These percentages were calculated from the total firewood consumption of 1,912,512 $\mathrm{kg}_{\text {year }}{ }^{-1}$. Meanwhile, every 15-20 years, MTPF contributed to 96.98\% of the total carpentry wood needs $\left(1,177.3 \mathrm{~m}^{3}\right)$ while the remaining $3.02 \%$ was supplied from privately owned gardens. This fact indicates that the dependence level of the community on the forest is high. Consequently, the pressure on the forest is also very high and may cause deforestation and degradation. To prevent deforestation and degradation, social participation in the sustainable management of MTPF is needed. The principles of social forestry must be implemented through social forestry programs such as community empowerment.
\end{abstract}

Keywords: contribution, firewood, carpentry wood, Mutis Timau Protected Forest

*Correspondence author, email: dakoxaverjurnal@gmail.com

\section{Introduction}

Forest is home to various potential resources, such as timber and non-timber forest products that can be utilized optimally and sustainably by human beings. Loaiza et al. (2015) cite that the community has a high level of dependence on forests and the environment. Furthermore, Simon (2003) argues that the growth of population demands the fulfillment of the community's needs, namely food, firewood, carpentry wood, and settlements. Communities living around the forest depend heavily on forest products to fulfill their daily needs. People collect woods from the forest for firewood or carpentry wood. The forest will suffer from degradation and deforestation if the dependence mentioned above is maintained and thus affecting the surrounding ecosystem.

The utilization of firewood and carpentry wood is vital for rural communities as it is the main and most readily available option in obtaining household energy needs, such as the need to cook, maintain body warmth, and build houses. FAO (2010) writes that as the oldest energy source, firewood is used by more than 2 billion people in developing countries for cooking and heating purposes. Nuryanti and Herdinie
(2007) state that energy plays an important role in people's life and constitutes an important parameter of the development and economic growth of all life sectors such as industry, household, transportation, services, etc. In the household sector, energy plays an important role in lighting, cooking, heating, and air conditioning as well as various other household activities.

The energy generated from firewood is important to maintain people's livelihood (Dresen et al. 2014). Firewood is the most important forest product for rural communities in developing regions and the scarcity of firewood can cause a serious problem (Cooke et al. 2008; Timko \& Kozak 2016). Arnold et al. (2006) state that, in many developing countries, firewood use is dominantly found in rural areas, while charcoal is more commonly used in urban areas. Brouwer and Falcao (2004) explain that the community in Mozambique (Maputo) is highly dependent on firewood to supply their energy needs. On the other hand, carpentry wood is needed by people throughout the world, both in urban and rural areas, in the construction of roofs, frames, doors, windows, pillars, and other house construction related items. 
Oñate-calvín et al. (2018) argue that the use of forest resources continuously increases as the distance to the markets in urban areas grows longer. The exploitation of forest resources has exceeded the carrying capacity of the forest itself and has caused environmental damages (deforestation and degradation) resulting in negative impacts such as global warming, flood, erosion, and landslide during the rainy season. Sulaiman et al. (2017) explain that firewood consumption contributes greatly to forest degradation.

Mutis Timau Protected Forest (MTPF) area is a forest group located in Timor Island. It is situated in the Forest Management Unit (FMU) of Timor Tengah Selatan District and is often dubbed as the lungs of Timor Island. MTPF is also the headwaters of two large watersheds, the Benain and Noelmina watersheds. As a forest group that is stretching from the lowland to the highland in Mutis Mountain, MTPF houses rich flora and fauna biodiversity with high potential for further improvements of the ecology, economy, and social life of the community. Njurumana (2016) states that the dynamics of the era and the increasing social knowledge of the people have contributed to the universal positioning of the religious value of flora biodiversity. Flora biodiversity is a strategic resource with various potential usages for human beings. The MTPFs' supply of firewood is sourced periodically weekly, monthly, and yearly, while its supply of carpentry wood is sourced every 15-20 years and will then be used to repair damaged houses or buildings or build new ones. Due to population growth, MTPF gets more pressure because it has to fulfill the community's ever-growing needs such as firewood, carpentry wood, settlements, and herding area. Therefore, the management of MTPF must focus on social needs and forest preservation that emphasizes the importance of a collaborative initiative involving the community members around MTPF.

Aside from the garden, the forest is the best option available for the people living in and around MTPF to get firewood and carpentry wood. The community gardens around MTPF are filled with food crops, vegetables, and plantation crops. Very few of those plants are capable of providing firewood and carpentry wood. At present, the consumption of firewood and carpentry wood of the rural households, especially those around MTPF, is uncertainly known. This preliminary study is meant to examine the contribution of MTPF, with all of its potential resources, to the community in fulfilling firewood and carpentry wood needs.

\section{Methods}

Location of the study The study was conducted in 9 (nine) villages around the FMU of MTPF area in TTS District. The villages are Nunbena, Noebesi, Leloboko, Tunua, Ajaobaki, Nuapin, Nenas, Kuanoel, and Fatumnasi (Figure 1).

This research took place from September 2017-January 2018. In general, MTPF, which is located in Timor Tengah Selatan District, is the former Model FMU of Mutis Timau with an area of 15,807 ha comprising of various types of land cover type, namely primary dryland forest (4,485.16 ha), secondary dryland (9,338.155 ha), shrub (1,491,965 ha), and dryland farming with shrub (491.735 ha) with a rainfall of 400 to 3,500 mm year ${ }^{-1}$. Furthermore, in terms of mountain topography, MTPF has various slope levels, namely moderately steep $(7,326.286$ ha), steep $(4,201.746$ ha), and very steep $(4,278.966 \mathrm{ha})$. There are various types of soil in MTPF, namely district cambisol $(3,619.186$ ha), usic cambisol (1,587.696 ha), humic latosol (5,697.846 ha), rendzina (4,228.256 ha), and latosol (674.016 ha). The land in MTPF also has several level of landslide vulnerability, namely rather vulnerable $(2,220.378$ ha), moderately vulnerable (8,723.868 ha), vulnerable (2,220.408 ha), and most vulnerable $(2,642.348$ ha).

Data collection and analysis The method employed in this study was the survey method utilizing descriptive analysis aimed at creating a systematic, factual, and accurate overview of the factors, characteristics, and correlation of the

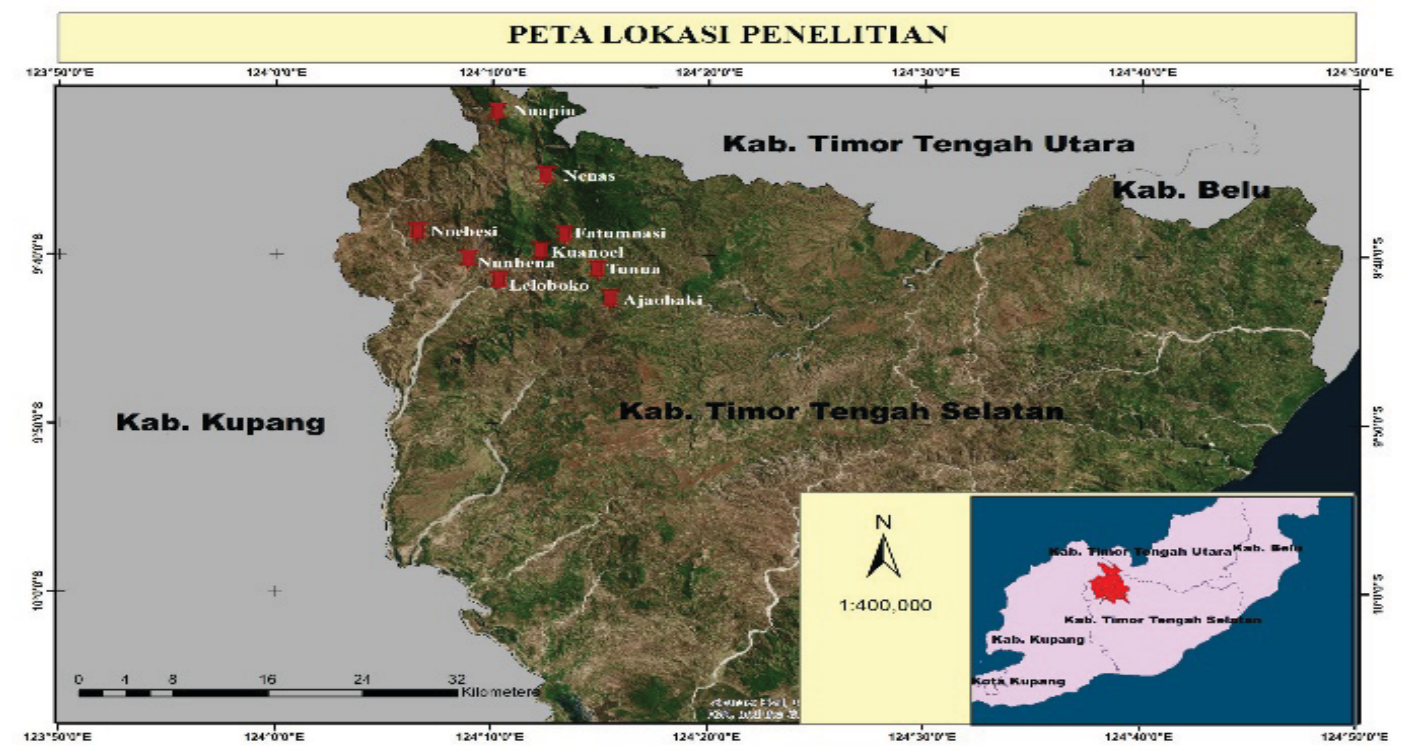

Figure 1 Place of the study. 
Table 1 Samples of respondents in each village

\begin{tabular}{lccr}
\hline \multicolumn{1}{c}{ Villages } & Population Number & Number of Households & Sampels (Households) \\
\hline Noebesi & 1,378 & 300 & 35 \\
Nunbena & 894 & 229 & 26 \\
Leloboko & 781 & 193 & 23 \\
Tunua & 1,798 & 421 & 50 \\
Ajaobaki & 1,893 & 407 & 48 \\
Nuapin & 2,249 & 545 & 53 \\
Nenas & 1,230 & 267 & 31 \\
Kuanoel & 1,231 & 316 & 37 \\
Fatumnasi & 1,589 & 425 & 50 \\
\hline Total & 13,043 & 3,103 & 353 \\
\hline
\end{tabular}

phenomena existing in the field. The population of this study was the total number of existing households, and the sampling technique utilized was the formula used by Sevilla et al. (1993) with an acceptable margin of error of $5 \%$. The sample of this study were 353 households selected proportionally from each village. The detailed data on the sample distribution is shown in Table 1.

This preliminary study used primary data and secondary data comprising the data on the use of firewood and carpentry wood. The scope of the study was limited to the firewood used by the households for cooking and carpentry wood used for building houses. The data collection methods used in this study were questionnaires, observation, direct measurements of firewood and carpentry wood owned by the respondents, in-depth interviews, documentation, and literature review.

The data analysis was focused on analyzing firewood and carpentry wood consumption. Firewood consumption was calculated by weighing (in $\mathrm{kg}$ ) the amount of firewood taken by the respondents from the forest or the garden. After weighing the firewood, the next step was calculating the firewood consumption per week and then calculating the total consumption for 1 year (2017). Simon (2004) explains that firewood needs are calculated by weighing and summing up the firewood needs, both those sourced from the forest and the garden, of all families per day $\left(\mathrm{kg} \mathrm{day}{ }^{-1}\right)$, and then dividing it by the total number of family members $(\mathrm{kg}$ person ${ }^{1}$ day $\left.^{-1}\right)$. Meanwhile, carpentry wood consumption is calculated based on the area of the house. In this method, the total amount of woods, as well as the size (length $\times$ height $\times$ width), needed for all of the respondents' houses, were calculated. Thus, the unit of measurement for respondents' carpentry wood is cubic meter $\left(\mathrm{m}^{3}\right)$. The next step was conducting interviews with respondents to learn the need for firewood and carpentry wood sourced from MTPF and the gardens.

\section{Results and Discussion}

Respondent characteristics The respondents of this study are the 353 households living around MTPF distributed proportionally in nine villages. The main occupation of these respondents is farming (100\%), with $89 \%$ of them are men and the remaining $11 \%$ are women. In terms of education level, $73.9 \%$ of the respondents belong to the primary school level, while $14.7 \%$ belong to the junior high school level, and the last $11.3 \%$ belong to the senior high school level.

In Dawan tribes' life, people believe in a noble philosophy that the forest is inseparable from the life of all humans and animals. When obtaining dry wood, they usually take a bundle of firewood consisting 25-30 small sticks with a perimeter less than $30 \mathrm{~cm}$ and irregular length (usually not longer than 2 meters). Upon arriving at home, the wood will then be used for cooking. Dawan people usually cook using a stove made out of three stones placed on the ground at a regular distance to form an equilateral triangle. Activities like cooking rice and vegetables, as well as water heating, require ten sticks. Sometimes, people spend one bundle or several bundles of dry wood a day to stay warm because seven out of the nine villages have low air temperature. The firewood consumption for cooking in each family is not the same since it depends on the number of family members.

The contribution of MTPF to firewood consumption Aside from becoming a source of income, MTPF also benefit the people by providing firewood. The MTPF contributes to as much as $87.45 \%$ of the firewood consumed by the community in the nine villages, while the remaining $12.55 \%$ was sourced from privately owned land (garden). The firewood consumption is shown in Table 2.

Table 2 indicates that from the total firewood consumption of the respondents in Nunbena, $88.36 \%$ was sourced from the forest and $11.64 \%$ was sourced from the gardens; in Noebesi, as much as $90.94 \%$ was sourced from the forest and $9.06 \%$ was sourced from the gardens; in Leloboko, 94.28\% was sourced from the forest and the remaining $5.72 \%$ was sourced from the gardens; in Tunua, $86.65 \%$ of the firewood was sourced from the forest and $13.35 \%$ was sourced from the gardens; in Ajaobaki, as much as $75.98 \%$ was sourced from the forest and $24.02 \%$ was sourced from the gardens; in Nuapin, $94.79 \%$ was sourced from the forest and 5.21\% was sourced from the gardens; in Nenas, $86.99 \%$ of the total consumption was sourced from the forest while the remaining $13.01 \%$ was sourced from the gardens; in Kuanoel, as much as $87.55 \%$ was sourced from the forests and $12.45 \%$ was sourced from the gardens; in Fatumnasi $86.33 \%$ was sourced from the forests and $13.67 \%$ was sourced from the garden. The contribution of MTPF to the firewood consumption is shown in Figure 2.

The contribution of MTPF to carpentry wood needs Carpentry woods from MTPF area are usually used for house construction. The result shows that when a house is $15-20$ years old, people tend to do house repair by replacing the damaged woods. Thus, the need for woodworking does not 
Table 2 Respondent's firewood consumption

\begin{tabular}{lcccccc}
\hline \multirow{2}{*}{ Villages } & \multicolumn{2}{c}{ Firewood consumption $\left(\mathrm{kg} \mathrm{week}^{-1}\right)$} & \multicolumn{3}{c}{ Firewood consumption $\left(\mathrm{kg} \mathrm{year}^{-1}\right)$} \\
\cline { 2 - 6 } & Forest & Garden & Total & Forest & Garden & Total \\
\hline Nunbena & 1,816 & 239 & 2,055 & 87,168 & 11,472 & 98,640 \\
Noebesi & 2,952 & 294 & 3,246 & 141,696 & 14,112 & 155,808 \\
Leloboko & 2,142 & 130 & 2,272 & 102,816 & 6,240 & 109,056 \\
Tunua & 3,980 & 613 & 4,593 & 191,040 & 29,424 & 220,464 \\
Ajaobaki & 4,239 & 1340 & 5,579 & 203,472 & 64,320 & 267,792 \\
Nuapin & 6,198 & 340 & 6,538 & 297,504 & 16,320 & 313,824 \\
Nenas & 3,158 & 472 & 3,630 & 151,584 & 22,656 & 174,240 \\
Kuanoel & 4,290 & 610 & 4,900 & 205,920 & 29,280 & 235,200 \\
Fatumnasi & 6,070 & 961 & 7,031 & 291,360 & 46,128 & 337,488 \\
\hline Total & 34,845 & 4,705 & 39,944 & $1,672,560$ & 239,952 & $1,912,512$ \\
\hline
\end{tabular}

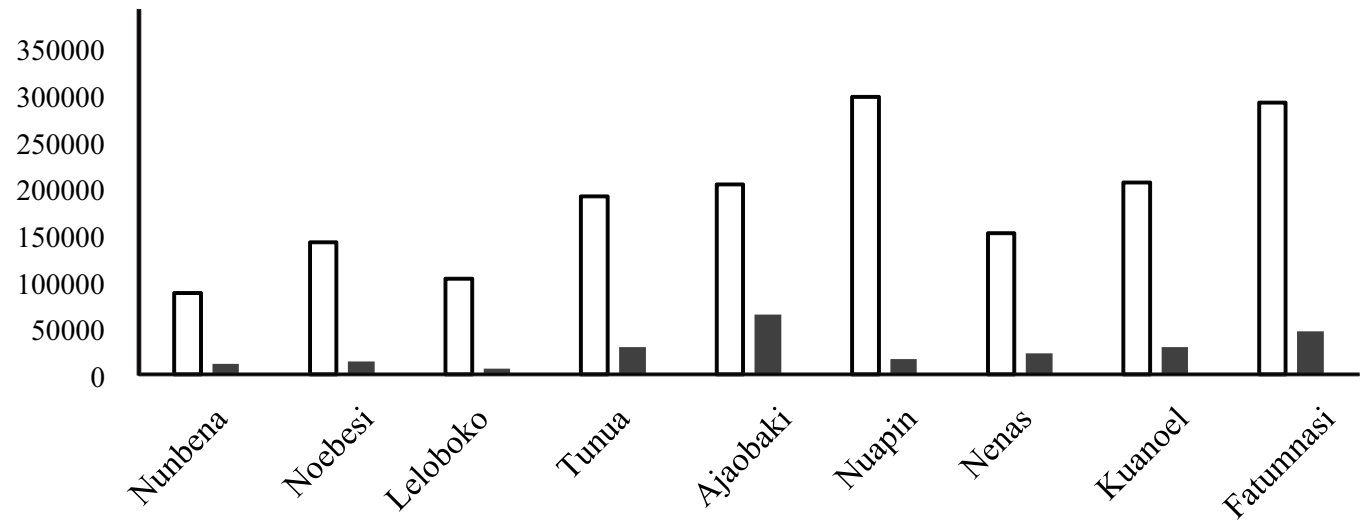

Figure 2 Firewood Consumption of the Respondents (kg year $\left.{ }^{-1}\right)$. Forest $(\square)$, Garden $(\square)$.

Table 3 The respondents' of wood carpentry consumption $\left(\mathrm{m}^{3} / 15-20\right.$ years $)$

\begin{tabular}{lccc}
\hline \multirow{2}{*}{ Villages } & \multicolumn{2}{c}{ Wood carpentry consumption $\left(\mathrm{m}^{3}\right)$} & \multirow{2}{*}{ Total $\left(\mathrm{m}^{3}\right)$} \\
\cline { 2 - 3 } & Forest & Garden & 78.5 \\
\hline Nunbena & 78.5 & 0.0 & 101.0 \\
Noebesi & 101.0 & 0.0 & 68.5 \\
Leloboko & 67.5 & 1.0 & 181.5 \\
Tunua & 158.5 & 23.0 & 156.0 \\
Ajaobaki & 156.0 & 0.0 & 175.5 \\
Nuapin & 175.0 & 0.5 & 108.5 \\
Nenas & 104.5 & 4.0 & 124.0 \\
Kuanoel & 121.5 & 2.5 & 183.8 \\
Fatumnasi & 179.3 & 4.5 & $1,177.3$ \\
\hline Total & $1,141.8$ & 35.5 & \\
\hline
\end{tabular}


occur periodically every year. As much as $96.98 \%$ of the woods used for house construction were sourced from the forest, while $3.02 \%$ of those were sourced from the gardens. The carpentry wood sourced from MTPF and was used for house construction in all the observed villages once every 15-20 years amounts $1,141.8 \mathrm{~m}^{3}$. The highest consumption was recorded in Fatumnasi $\left(179.3 \mathrm{~m}^{3}\right)$ while the lowest was recorded in Leloboko $\left(67.5 \mathrm{~m}^{3}\right)$. Meanwhile, in terms of carpentry wood that was obtained from the gardens, the highest consumption was recorded in Tunua $\left(23 \mathrm{~m}^{3}\right)$ and the lowest was recorded in NunbenaNunbena and Ajaobaki with $0 \mathrm{~m}^{3}$. The consumption of carpentry wood produced by MTPF is shown in Table 3.

Table 3 explains that $100 \%$ of the carpentry wood used in Nunbena was sourced from the forest; in Noebesi, 100\% was sourced from the forests; in Leloboko, as much as $98.54 \%$ was sourced from the forests and $1.46 \%$ was sourced from the gardens; in Tunua, $87.32 \%$ was sourced from the forest and $12.68 \%$ was sourced from the gardens; in Ajaobaki, $100 \%$ of the carpentry wood was sourced from the forest; in Nuapin, $99.71 \%$ of its carpentry wood was sourced from the forest while the remaining $0.29 \%$ was sourced from the gardens; in Nenas, $96.31 \%$ was sourced from the forest and $3.69 \%$ was sourced from the gardens; in Kuanoel, $97.98 \%$ was sourced from the forest and $2.02 \%$ was sourced from the gardens; and in Fatumnasi, as much as $97.55 \%$ was sourced from the forest and the remaining $2.45 \%$ was sourced from the gardens. Carpentry wood consumption varies between respondents in each village, and depends on the size of the house. The carpentry wood consumption in the observed villages is shown in Table 4 .

The contribution of MTPF to the carpentry wood consumption within the period of 15-20 years can be observed in Figure 3. Berger et al. (1988) assert that people with traditional (old) cultures are highly integrated and firmly united under the order established using religious rules, while more modern societies experience a segmentation or pluralization process. Within the context of the use of firewood and carpentry wood, people with traditional cultures are still bound together by their collective dependence on MTPF woods used for cooking and house construction. This dependency is supported by the order

Table 4 Total area of respondents' houses

\begin{tabular}{|c|c|c|c|c|c|c|c|c|c|c|c|c|c|c|}
\hline \multirow{2}{*}{$\begin{array}{c}\text { Villages } \\
(\%)\end{array}$} & \multicolumn{14}{|c|}{ Total area of respondents' houses $\left(\mathrm{m}^{2}\right)$} \\
\hline & 20 & 24 & 28 & 30 & 35 & 42 & 48 & 56 & 63 & 70 & 72 & 80 & 96 & 120 \\
\hline Nunbena & - & - & - & 11.54 & 7.69 & 30.77 & 23.08 & 3.85 & 3.85 & 3.85 & 11.54 & 3.85 & - & - \\
\hline Leloboko & - & - & - & 13.00 & 17.40 & 34.80 & 21.70 & 4.30 & - & - & 8.70 & - & - & - \\
\hline Tunua & - & 14.00 & 6.00 & & 16.00 & 20.00 & 24.00 & 10.00 & 6.00 & - & 2.00 & 2.00 & - & - \\
\hline Nuapin & 5.66 & 15.09 & 1.89 & 13.20 & 15.09 & 16.98 & 18.87 & 3.77 & 5.66 & - & 3.77 & - & - & - \\
\hline Nenas & 3.22 & 16.13 & - & 3.22 & 22.58 & 16.13 & 19.35 & 9.68 & 9.68 & - & - & - & - & - \\
\hline Kuanoel & - & 5.40 & - & 21.60 & 8.10 & 37.80 & 18.90 & - & 8.10 & - & - & - & - & - \\
\hline Fatumnasi & - & 4.00 & - & 14.00 & 28.00 & 8.00 & 30.00 & 4.00 & 2.00 & - & 2.00 & - & 4.00 & 4.00 \\
\hline
\end{tabular}

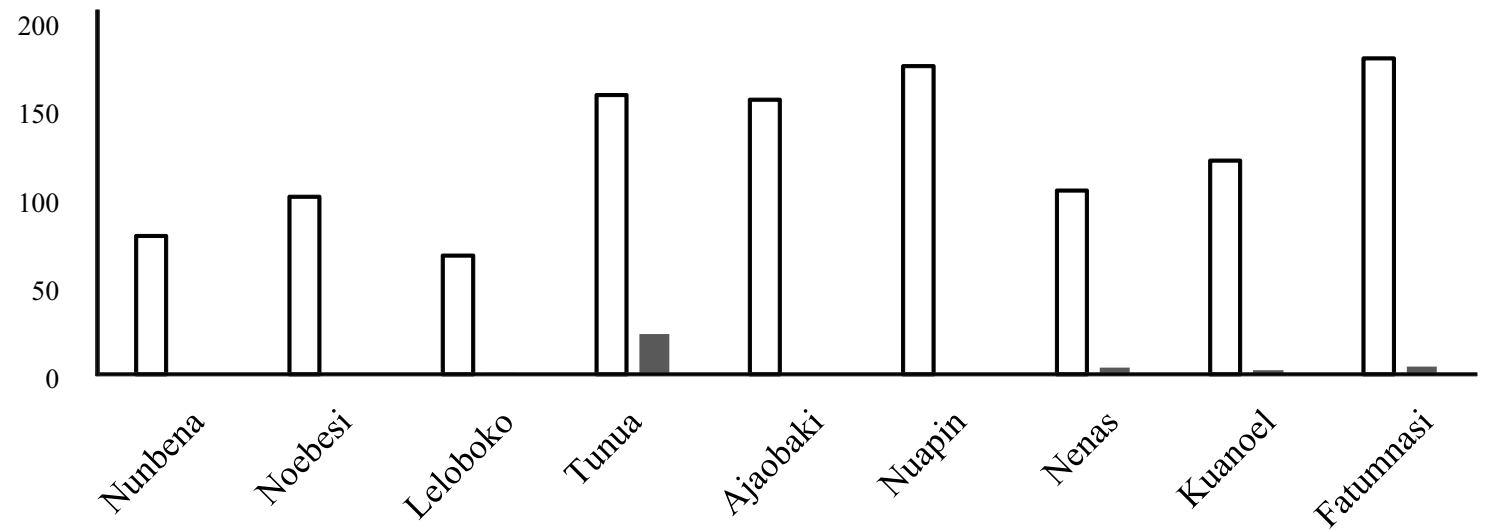

Figure 3 Wood carpentry consumption of the respondents $\left(\mathrm{m}^{3} / 15-20\right.$ years). Forest ( $\left.\square\right)$, Garden ( $\square$ ). 
induced by the dominant religion of the people who live around MTPF (Protestantism) encouraging the people to form a united community collectively utilizing the surrounding resources. In addition, they also use firewood and carpentry wood as the energy sources of their household as well as house construction. On the other hand, in terms of the utilization of firewood and carpentry wood, the modern societies are experiencing a differentiation due to the heterogeneity of the community and the two commodities. As a result, community members have an option to substitute both commodities with other commodities, such as kerosene and LPG for cooking or light steel for building houses. Thus, it is apparent that the traditional society is based in the rural areas (periphery) and outskirts of city (semi-periphery), while the modern society is in the city (core).

Hopkins and Wallerstein (1988) divide the economic progress of the world community into three, namely developed economy (core), underdeveloped economy (periphery), and the one in-between them. Within the context of the use of firewood in Indonesia, especially in the location of this study, the use of firewood is actually more dominant in the periphery and semi-periphery regions. The people living in and around MTPF belong to the periphery category, while the people living in Fatumnasi, Nunbena, and Mollo Subdictrict capital of Timor Tengah Selatan (TTS) District belong to the semi-periphery category. The people living in the capital of TTS, which is in So'E, are categorized as the core. Likewise with the use of wood carpentry for house construction, for periphery and semi-periphery societies, wood carpentry is the main commodity, while in core society, it can be substituted by other materials, such as light steel.

For rural societies and the poor who live in urban areas, firewood is used as the main energy source in meeting their daily needs such as for cooking and warming up their bodies or other needs and highly dependent on wood availability in the forest. Nepal et al. (2017) state that most rural and agricultural households in Nepal depend on the forests for firewood and animal feed. Asfaw et al. (2013) cite that firewood is the most utilized forest product with the highest contribution (79\%) to forest income. Kebede et al. (2010) describe that wood fuel contributes to $70 \%$ of the world's energy consumption, followed by petroleum as the second most-contributing fuel. Additionally, most industrial activities make use of some types of wood fuel. Most of the people in the FMU of MTPF in TTS District use firewood for cooking purposes. The result of the survey reveals that almost every day and at least every two days, the people will collect firewood from MTPF. The activity of collecting firewood has taken place for a very long. Firewood is the main energy source for cooking activities performed by the rural communities around MTPF.

As the main raw material for household energy used in daily cooking needs as well as for house construction and repair every 15-20 years, firewood and carpentry wood are indispensable for the people living in and around MTPF. This is supported by the availability of plants capable of producing firewood and carpentry wood in MTPF and Mutis Nature Reserve. Some dominant plants, such as Eucalyptus alba, Melaleuca Leucadendron, Casuarina equisetifolia, and some other less dominant plants such as Cassia siamea, Swiethenia macrophylla, Tectona grandis, and Acacia leucophloea grow in MTPF and serve as the raw materials provider for firewood and carpentry wood.

The people's habit of sourcing firewood and carpentry wood from several types of plants is perpetuated by the fact that these communities live not far from the MTPF area. Due to being close to MTPF and being far from any conventional markets in urban areas that provide various commodities that can be used as the source of household energy and house construction, firewood, and carpentry wood have become indispensable for these communities for a long time. In the MTPF area, there are a lot of firewood in the form of dry woods falling down from the trees and scattered throughout the forest floor. From the total firewood consumption of $1,912,512 \mathrm{~kg}$ year $^{-1}$, the firewood sourced from the gardens can only contribute as much as $12.55 \%$ or $239,952 \mathrm{~kg}_{\text {year }}{ }^{-1}$, while the remaining $87.45 \%\left(1,672,560 \mathrm{~kg}\right.$ year $\left.{ }^{-1}\right)$ is sourced from the dry woods falling from the trees and scattered throughout the forest floor or cut branches, twigs, and even trees. Similarly, from the total carpentry wood used by the respondent in house construction every 15-20 years is $\left(1,177.3 \mathrm{~m}^{3}\right)$, only $3.02 \%$ can be supplied by privately owned land (gardens) and the majority $(96.98 \%)$ is sourced from MTPF.

In average, the firewood consumption in the nine villages around the FMU of MTPF in TTS District is $1,273.13 \mathrm{~kg}$ capita $^{-1}$ year $^{-1}$. In Noebesi, the average firewood consumption is $971.8 \mathrm{~kg}$ capita $^{-1}$ year $^{-1}$; in Nunbena, the average consumption is $969.15 \mathrm{~kg}$ capita $^{-1}$ year $^{-1}$; in Leloboko, the average consumption is $1,171.73 \mathrm{~kg}_{\text {capita }}{ }^{-1}$ year $^{-1}$; in Tunua, the average firewood consumption is 1,032.42 kg capita $^{-1}$ year ${ }^{-1}$; in Ajaobaki the average consumption is $1,221 \mathrm{~kg}$ capita $^{-1}$ year $^{-1}$; in Nuapin, the average consumption is $1,434.88 \mathrm{~kg}_{\text {capita }}{ }^{-1}$ year $^{-1}$; in Nenas the average consumption is $1,220.09 \mathrm{~kg} \mathrm{month}^{-1}$; in Kuanoel the average consumption is $1,631.79 \mathrm{~kg}_{\text {capita }}{ }^{-1} \mathrm{year}^{-1}$; and in Fatumnasi, the average firewood consumption is $1,805.31 \mathrm{~kg}$ capita $^{-1}$ year $^{-1}$. Astana (2012) states that the carpentry wood consumption of the rural households in Sukabumi District is $256 \mathrm{~kg}$ month $^{-1}$, while in Banjarnegara District it is $206 \mathrm{~kg}$ month $\mathrm{kg}$ capita $^{-1}$ year $^{-1}$, and in Lebak district it is $165 \mathrm{~kg}$ month $^{-1}$. Win et al. (2018) state that the consumption of carpentry wood per capita in Myanmar is $780 \mathrm{~kg}$ year $^{-1}$.

The consumption of firewood of the households in 9 sample villages around the MTPF area is very high. In contrast to the result of Dwiprabowos' (2010) study, the number of households that consume firewood in Banjarnegara, Sukabumi, and Lebak is quite high $(90 \%$, $70 \%$, and $50 \%$, respectively). All of the firewood obtained by the respondents from the FMU of MTPF area and the gardens are used for cooking. Similarly, in his research on the use of firewood in Guinea, Central Africa, Gelabert et al. (2011) state that most of the firewood collected from gardens are used for cooking. Firewood-collecting firewood is an integral part of the socio-economic aspect of the life of premodern society. Reyes et al. (2018) illustrates that the wood obtained from the native forests are mainly used as firewood (93\% of the total wood taken from native forests) and $70 \%$ of these forests are in privately owned land.

MTPF has given a lot of benefits to the rural and suburban societies dealing in terms of the supplies of firewood as 
the main raw material for household energy and cooking as well as the supplies of carpentry wood needed in house construction. This is in line with the theories suggesting that the people living around the forest area are dominated by the poor who are dependent on firewood for cooking and carpentry wood for house construction. The huge contribution of MTPF to firewood and carpentry wood needs encourages the management and community to preserve MTPF and avoid everything that can cause damage to the protected forests, especially anthropogenic damage.

However, the growth of the population of the nine villages around will undoubtedly affect the level of firewood consumption. Perhaps, in the future, the supply of firewood obtained from MTPF will decrease because the forest is experiencing deforestation and degradation. Therefore, the government must make a breakthrough, protected forest management using social forestry principles based on local wisdom. The core philosophy of the local community (the Dawan tribe) suggesting that the forest, human, and animals are inseparable. This is reflected in the saying: "mansian, mu'it, nasi kan bisa batief, faut makono, hau makono, fatu nane on au nuiffa kuk, o'el na au na'e kuk, nasi nane au nak fun fa kun, pao kuan, pao nasi (the forest is inseparable from human and animals because of the bearded stones and bearded trees bearing similar features to those of human beings)". The Dawan people believe that the stone symbolizes bones, the water symbolizes blood, and the forest symbolizes hair. These inanimate objects always guard the village and the forest and display features similar to those of the human. By believing in this philosophy, the people around MTPF will feel encouraged to protect the existence of the protected forest since it gives various benefits for the sake of both human prosperity and the preservation of forest ecosystems.

Considering the existence of such belief, social forestry should be able to be used as a solution to solve the problems experienced by the people living around the forest, especially poverty, because social forestry can guarantee forest sustainability through the role of humans as managers and users as well as the fulfillment of needs through the preservation of plants and animals. In implementing the social forestry strategy to overcome the scarcity of firewood and carpentry wood, plants yielding firewood and carpentry wood must be planted in both MTPF and community owned land. By doing this, the main goal, forest preservation and community prosperity, can be achieved.

Pique et al. (2016) suggest that social needs will play a more prominent role as a determining factor in the planning of carpentry wood and firewood provision strategies than adaptation to nature's carrying capacity. Sahoo (2015) also argues that the social forestry program will provide not only food, animal feed and shelter for the people, but also considerable income for the government. The social forestry program can improve the socio-economic condition of the people and the nation and have a huge impact on the national and global levels. Thus, the core of social forestry is collaborative management that is very beneficial for community welfare and the preservation of the forest. Waka and Awang (2017) state that in relation to the management of conservation areas, collaborative management is the most appropriate strategy to accommodate the interest of the surrounding community. In addition, Paudel (2018) argues that if the forest is managed properly by the people it can be used as an effective way to overcome food vulnerability in rural households with lower levels of social capital. Kurniadi et al. (2017) state that the development of a protected forest is considered as a way to conserve biodiversity and ecosystem services. To maintain the sustainability of MTPF with the social forestry program, the government should commit to the social welfare of the community around the forest through the implementation of social empowerment programs. Furthermore, Setiajiati et al. (2017) state that social empowerment programs are highly effective in changing people's view to the conservation of protected forests.

\section{Conclusion}

MTPF gives a very significant contribution to the primary needs of the community, especially in terms of the utilization of forest timber products for firewood and carpentry wood. The conclusion above is corroborated by the fact that from the total firewood consumption of the community in the nine villages $(1,912.512) \mathrm{kg}$ year $^{-1}$, $87.45 \%$ was sourced from MTPF while the remaining $12.55 \%$ was sourced from the gardens. Additionally, from the total consumption of carpentry wood used in building the people's houses every $15-20$ years $\left(1,177.3 \mathrm{~m}^{3}\right.$ year $\left.{ }^{-1}\right)$, $96.98 \%$ was sourced from MTPF, while the remaining $3.02 \%$ was sourced from the gardens. The community's high dependence on the forest can cause deforestation and degradation. To solve the problems on deforestation and degradation that is potentially found within the MTPF area, the management must formulate a forest management concept based on the principles of social forestry which always prioritizes social welfare and forest sustainability. The principles of social forestry are implemented by performing social forestry programs that involve the community's participation in MTPF management, such as community empowerment programs. Thus, MTPF can continuously contribute greatly to provide the primary needs of the community.

\section{Acknowledgement}

The authors would like to thank the Ministry of Research, Technology and Higher Education for providing the opportunity to continue the BUDI-DN Doctoral Education Program and the Ministry of Finance for providing research funding and educational facilities during the study through the Indonesia Endowment Fund for Education (LPDP). The writers would also want to express their gratitude to the respondents and the staffs of the FMU in TTS District who have provided valuable information for the development of science, especially in the writing process of this article

\section{References}

Arnold JEM, Köhlin G, Persson R. 2006. Woodfuels, livelihoods, and policy interventions: Changing perspectives. World Development 34(3):596-611. 
https://doi.org/10.1016/j.worlddev.2005.08.008.

Asfaw A, Lemenih M, Kassa H, Ewnetu Z. 2013. Importance, determinants and gender dimensions of forest income in eastern highlands of Ethiopia: The case of communities around Jelo Afromontane forest. Forest Policy and Economics 28:1-7. https://doi.org/10.1016/ j.forpol.2013.01.005.

Astana S. 2012. Konsumsi kayu bakar rumah tangga pedesaan dan faktor-faktor yang mempengaruhi di Kabupaten Banjarnegara Jawa Tengah, Sukabumi Jawa Barat dan Lebak Banten. Jurnal Ilmu Kehutanan Penelitian Sosial dan Ekonomi Kehutanan 9:229-241.

Berger PL, Berger B, Kellner H. 1988. Pluralitas dunia kehidupan sosial. In: Hans-Dieter Evers, editor. Teori Masyarakat: Proses Peradaban Dalam Sistem Dunia Modern. Jakarta: Yayasan Obor Indonesia.

Brouwer R, Falcao P. 2004. Wood fuel consumption in Maputo, Mozambique. Biomass and Bioenergy 27(3):233-245. https://doi.org/10.1016/j.biombioe. 2004.01.005.

Cooke P, Köhlin G, Hyde WF. 2008. Fuelwood, forests and community managementevidence from household studies. Environment and Development Development Economics 13(1):103-135. https://doi.org/10.1017/ S1355 770X0700397X.

Dresen E, deVries B, Herold M, Verchot L, Müller R. 2014. Fuelwood savings and carbon emission reductions by the use of improved cooking stoves in an Afromontane Forest, Ethiopia. Land 3(3):1137-1157. https://doi.org/10.3390/land3031137.

Dwiprabowo H. 2010. Kajian kebijakan kayu bakar sebagai sumber energi di pedesaan Pulau Jawa. Jurnal Analisis Kebijakan Kehutanan 7:1-11.

FAO. 2010. What woodfuels can do to mitigate climate change. In FAO Forestry Paper 162. Rome: Food and Agriculture Organization of The United Nations.

Gelabert L, Asouti E, Marti EA. 2011. The ethnoarchaeology of firewood management in the Fang villages of Equatorial Guinea, Central Africa: Implications for the interpretation of wood fuel remains from archaeological sites. Journal of Anthropological Archaeology 30:375-384. https://doi.org/10.1016/j.jaa.2011.05.002.

Hopkins TK, Wallerstein I. 1988. Pola-pola Pembangunan Sistem Dunia Modern, Usulan Penelitian. In: HansDieters Evers, editors. Teori Masyarakat: Proses Peradaban Dalam Sistem Dunia Modern. Jakarta: Yayasan Obor Indonesia. Jakarta.

Kebede E, Kagochi J, Jolly CM. 2010. Energy consumption and economic development in Sub-Sahara Africa. Energy Economics 32(3):532-537. http://doi.org/10.1016/j. eneco.2010.02.003.
Kurniadi R, Purnomo H, Wijayanto N, Fuah AM. 2017. The refusal of livestock owners towards exclusion policy in protected area. Jurnal Manajemen Hutan Tropika 23(1):16-24. https://doi.org/10.7226/jtfm.23.1.16.

Loaiza T, Nehren U, Gerold G. 2015. REDD ${ }^{+}$and incentives: An analysis of income generation in forest-dependent communities of the Yasuní Biosphere Reserve, Ecuador. Applied Geography 62:225-236. https://doi.org/10. 1016/j.apgeog.2015.04.020.

Nepal M, Nepal AK, Berrens RP. 2017. Where gathering firewood matters: Proximity and forest management effects in hedonic pricing models for rural Nepal. Journal of Forest Economics 27:28-37. https://doi.org/10.1016/j.jfe.2017.02.005.

Njurumana GN. 2016. Masyarakat desa dan manajemen biodiversitas flora pada sistem pekarangan di Kabupaten Sumba Tengah. Jurnal Penelitian Kehutanan Wallacea $1: 25-36$.

Nuryanti S, Herdinie SS. 2007. Analisis karakteristik konsumsi energi pada sektor rumah tangga di Indonesia. In Proceedings of Seminar Nasional III SDM Teknologi Nuklir Yogyakarta, 21-22 November 2007.

Oñate-calvín RD, Oviedo JL, Salo M. 2018. Forest resourcebased household economy in the communities of the Nanay River Basin, Peruvian Amazonia. Ecological Economics 146:218-227. https://doi.org/10.1016/ j.ecolecon.2017.10.012.

Paudel J. 2018. Community-managed forests, household fuelwood use and food consumtion. Ecological Economics 147:62-73. https://doi.org/10.1016/ j.ecolecon.2018.01.003.

Pique R, Revelles J, Burjachs F, Ferme LC, Pérez-Obiol R. 2016. Interdisciplinary approach to the landscape and firewood exploitation during the Holocene at $\mathrm{La}$ Garrotxa (Girona, NE Iberia). Quaternary International 463(B):401-413. https://doi.org/10.1016/j.quaint.2016. 11.025

Reyes R, Nelson H, Zerrif H. 2018. Firewood: Cause or consequence? Underlying drivers of fi rewood production in the South of Chile. Energy for Sustainable Development 42:97-108. https://doi.org/10.1016/j.esd. 2017.10.006.

Sahoo B. 2015. Social Forestry- A Case Study of The District of North 24-Parganas In West Bengal. International Journal of Research Granthaalayah 3(6):73-83.

Setiajiati F, Hardjanto, Hendrayanto. 2017. Strategies of community empowerment to manage protection forest sustainably. Jurnal Manajemen Hutan Tropika 23(2):71-80. https://doi.org/10.7226/jtfm.23.2.71.

Sevilla CG, Tuwu A, Syah A. 1993. Pengantar Metode Penelitian. Jakarta. Universitas Indonesia Press. 
Simon H. 2003. Hutan Jati dan Kemakmuran. Problematika dan Strategi Pemecahannya, Yogyakarta: Bigraf Publising Yogyakarta.

Simon H. 2004. Aspek Sosio-Teknis Pengelolaan Hutan Jati di Jawa. Yogyakarta: Penerbit Pustaka Pelajar.

Sulaiman C, Abdul-Rahim AS,Mohd-Shahwahid HO, Chin L. 2017. Wood fuel consumption, institutional quality, and forest degradation in sub-Saharan Africa: Evidence from a dynamic panel framework. Ecological Indicators 74:414-419. http://doi.org/10.1016/j.ecolind.2016. 11.045 .

Timko JA, Kozak RA. 2016. The influence of an improved firewood cookstove, Chitetzo mbaula, on tree species preference in Malawi. Energy for Sustainable Development 33:53-60. https://doi.org/10.1016/ j.esd.2016.04.002.

Waka A, Awang SA. 2017. Skenario pengembangan pengelolaan kolaborasi Taman Nasional Bantimurung Bulusaraung, Provinsi Sulawesi Selatan. Jurnal Penelitian Kehutanan Wallacea 6:31-40.

Win ZC, Mizouec N, Ota T, Kajisa T, Yoshida S, Oo TN, Hwan-ok M. 2018. Differences in consumption rates and patterns between fi rewood and charcoal: A case study in a rural area of Yedashe Township, Myanmar. Biomass and Bioenergy 109:39-46. https://doi.org/10.1016/ j.biombioe.2017.12.011. 